\title{
Hubungan Pengetahuan, Media Massa dan Lingkungan Dengan Sikap Remaja Putra Tentang Bahaya Rokok Pada Siswa SMA Negeri 4 Banda Aceh Tahun 2016
}

\author{
Related Knowledge, Media And Environment With Attitude Teen Son of \\ Danger Cigarettes in Student SMA State 4 Banda Aceh Year 2016 \\ Putri Husainah ${ }^{1}$, Nuzulul Rahmi*² \\ 1,2Prodi D-III Kebidanan Fakultas Ilmu Kesehatan Universitas Ubudiyah Indonesia, Banda Aceh, Indonesia \\ *Korespondensi Penulis : nuzululrahmi.uui.ac.id
}

\begin{abstract}
Abstrak
Merokok merupakan masalah yang belum dapat terselesaikan hingga saat ini.Merokok sudah melanda berbagai kalangan masyarakat di Indonesia,baik anak-anak sampai orang tua,lakilaki maupun perempuan, Salah satu sasaran program perilaku sehat dan pemberdayaan masyarakat adalah menurunnya prevalensi perokok serta meningkatnya lingkungan sehat bebas rokok di sekolah, tempat kerja dan tempat umum Dengan Jumlah siswa keseluruhan dari kelas I sampai dengan Kelas III berjumlah 190 siswa. Bersifat analitik dengan pendekatan Cross Sectional. Populasi semua siswa laki-laki tingkat I,II dan III yang ada di SMA N 4 Banda Aceh tahun 2016, yang berjumlah 190 orang. Pengambilan sampel 65 siswa, menggunakan dengan Proporsional sampling, Pengumpulan data dilakukan dengan menyebarkan kuesioner. Kemudian di uji statistik menggunakan Chi-square. Penelitian ini dari uji chi-square dari sikap positif tentang bahaya rokok lebih banyak pada responden yang lingkungan mendukung yaitu 75,8\%, dengan $\mathrm{p}$-value $=0,017$. responden yang pengaruh dengan media massa yaitu $73,7 \%$, dengan p-value $=0,016$, pada responden yang berpengetahuan baik yaitu $74,3 \%$, dengan $p$-value $=0,022$. Ada hubungan antara lingkungan media massa dan pengetahuan dengan sikap remaja putra tentang bahaya rokok pada siswa. Sebagai bahan informasi di setiap ruangan kelas agar siswa dapat mengetahui bahaya dari rokok dengan menempel poster pada setiap ruang kelas.
\end{abstract}

Kata Kunci: Pengetahuan, Media Massa, Lingkungan, Sikap

\begin{abstract}
Smoking is a problem that can not be resolved until today. Smoking has hit various communities in Indonesia, both children to the elderly, men and women amounted to overall student from class I to Class III totaled 287 students, from interviews 10 people on a student only $2(20 \%)$ of people who do not smoke because of damage to the health of oneself, and 8 (80\%) of people who smoke. To determine the relationship of knowledge, mass media and the environment with young men about the dangers of smoking in students SMA Negeri 4 Banda Aceh 2016. Characteristically analytic with cross sectional approach. The population of all male students 1-III levels in SMA N 4 Banda Aceh in 2015, totaling 190 student. sample of 65 students, using the Proportional sampling, data collection was done by distributing questionnaires. Then tested using Chi-square statistic, Ho is rejected if the $p$ value $>0.05$ and Ha accepted if $p$ value <0.05. from the environment to support more the attitude of teenagers
\end{abstract}


who agree about the dangers of smoking is $75,8 \%, p=0.017$, which gets more mass media attitude of teenagers who agree about the dangers of smoking is 73,7\%, $p=0.016$. good knowledge more adolescent attitude who agree about the dangers of smoking is $74.3 \% \mathrm{p}=$ 0.022. There is a relationship between the media environment and knowledge with the attitudes of young men about the dangers of smoking in students. Expected As an input to develop the science of signs about the dangers of smoking in students.

Keywords: Knowledge, Media And The Environment With Attitude Young Men About Dangers of Smoking.

\section{PENDAHULUAN}

Remaja adalah harapan bangsa,sehingga tidak berlebihan jika dikatakan bahwa masa depan bangsa akan ditentukan pada keadaan remaja saat ini. Remaja yang sehat dan berkualitas menjadi perhatian serius bagi orang tua, praktisi pendidikan, ataupun remaja itu sendiri. Remaja yang sehat adalah remaja yang produktif dan kreatif sesuai dengan tahap perkembangannya. Remaja dalam perkembangannya, sangat rentan terhadap pengaruh lingkungan. Lingkungan sosialbudayayang negative merupakan factor bagi remaja untuk terjebak dalam perilaku yang tidak sehat, misalnya merokok, minum minuman keras, penggunaan narkoba, sekspranikah, tawuran, tindakan kriminal, dan kebut-kebutan di jalan. Perilaku remaja yang dianggap menyimpang ini sangat berisiko terhadap kesehatan dan keselamatan mereka (Tarwotoetal, 2011).

Remaja merupakan masa yang paling rawan akan pengaruh dari lingkungan. Pergaulan mempengaruhi seseorang dan berkaitan dengan kebiasaan merokok. Pengaruh teman dan kelompok sangat kuat bagi seorang remaja memutuskan merokok atau tidak. Remaja akan berusaha mengikuti kebiasaan dari kelompok atau teman agar diterima dikelompok tersebut. Hal ini juga dapat disebabkan rasa percaya diri yang rendah sehingga cenderung mengadopsi kebiasaan yang berlaku seperti kebiasaan merokok (BPOMRI, 2011).

Kebiasaan merokok sudah menjadi budaya pada bangsa Indonesia. Remaja, dewasa, bahkan anak-anak sudah tidak asing lagi dengan benda mematikan tersebut. Perilaku merokok yang dilakukan oleh remaja sering kita lihat di berbagai tempat, misalnya di warung dekat sekolah, perjalanan menuju sekolah, haltebus, kendaraan pribadi, angkutan umum, bahkan dilingkungan rumah. Hal ini sudah menjadi pemandangan yang biasa dan jarang mendapat perhatian masyarakat, padahal perilaku tersebut berbahaya bagi remaja dan orang di sekitarnya (Kemenkes RI, 2012). 
Merokok merupakan masalah yang belum dapat terselesaikan hingga saat ini. Merokok sudah melanda berbagai kalangan masyarakat di Indonesia, baik anak-anak sampai orang tua, laki-laki maupun perempuan. Salah satu sasaran program perilaku sehat dan pemberdayaan masyarakat adalah menurunnya prevalensi perokok serta meningkatnya lingkungan sehat bebas rokok disekolah, tempat kerja dan tempat umum(KemenkesRI, 2010).

Menurut WHO (2010) setiap 6,5 detik satu orang meninggal karena rokok. Riset WHO memperkirakan bahwa orang yang mulai merokok pada usia remaja (70\% perokok pada usia dini) dan terus menerus merokok sampai 2 dekade atau lebih, akan meninggal 20-25 tahun lebih awal dari orang yang tidak pernah menyentuh rokok. Menurut Saprudin (2010) dalam Tarwoto etal, alasan remaja di Depok, Jawa Barat merokok adalah karena melihat teman $(28,43 \%)$, melihat orang tua / keluarga $(19,61 \%)$, melihat took hartis ditelevisi $(16,66 \%)$, melihat guru $(9,8 \%)$,menghilangkan stress $(3,92 \%)$, dan karena tidak pernah mendapatkan informasi tentang bahaya merokok $(10,79 \%)$.

Prevalensi perokok laki-laki yang diperkotaan pada yang tidak pernah sekolah 65,6\% dan pada yang SD71,2\%. Prevalensi perokok yang dipedesaan lebih tinggi disbanding yang diperkotaan. WHO (2010) menyatakan, didaerah pedesaan jumlah batang rokok yang dikonsumsi sedikit lebih banyak dibandingkan daerah perkotaan, baik pada laki-laki maupun perempuan. Menurut karakteristik tempat tinggal, prevalensi perokok dipedesaan $37,4 \%$ dan di perkotaan 32,3\% (Riskesdas, 2010).

Data Global Youth Tobacco Survey (GYTS) menunjukkan terjadi peningkatan perokok remaja yang cukup mengkhawatirkan. Prevalensi merokok terus meningkat baik pada laki-laki maupun perempuan. Prevalensi merokok pada perempuan meningkat empat kali lipat dari 1,3\% pada tahun 2008 menjadi 5,2\% pada tahun 2010. Menurut Global Youth Tobacco Survey (GYTS) (2011) 30,4\% remaja usia 13-15 tahun pernah merokok $(57,8 \%)$ laki-laki pernah merokok dan 6,4\% perempuan pernah merokok),dan 20,3\% remaja usia 1315 adalah perokok aktif (BPS, 2011).

Indonesia menduduki peringkat ke-3 dengan jumlah perokok terbesar di dunia setelah China dan India dan tetap menduduki posisi ke-5 setelah China, Amerika Serikat, Rusia dan Jepang pada tahun 2007 (WHO,2008). Lebih dari 40,3 juta anak Indonesia berusia 0-14 tahun terpapar dengan asap rokok (menjadi perokok aktif maupun perokok pasif). Hal ini menyebabkan perkembangan pertumbuhan paru anak tersebut menjadi lambat,dan lebih mudah terkena infeksi saluran pernafasan, infeksi telinga dan asma (KemenkesRI, 2010). 
Pemerintah Republik Indonesia telah mengatur kebijakan pelarangan merokok dalam peraturan pemerintah Republik Indonesia Nomor 19 Tahun 2003 tentang pengamanan rokok bagi kesehatan pasal 22 mengenai Kawasan Tanpa Rokok (KTR). Tempat umum sarana kesehatan, tempat kerja dan tempat yang secara spesifik sebagai proses belajar mengajar, arena kegiatan anak, tempat ibadah dan angkutan umum dinyatakan sebagai kawasan tanpa rokok. Penetapan KTR di suatu wilayah pada dasarnya adalah kebijakan untuk perlindungan terhadap perokok pasif, remaja, ibu hamil dan kelompok rentan, terhadap dampak kesehatan akibat asap rokok, serta pencemaran udara dalam ruang (Kemenkes,2012).

Hasil studi pendahuluan awal yang dilakukan oleh peneliti di SMA Negeri 4 Banda Aceh berjumlah siswa keseluruhan dari kelas I sampai dengan Kelas III berjumlah 287 siswa, dari hasil wawancara 10 orang pada siswa hanya $2(20 \%)$ orang yang tidak merokok karena merusak bagi kesehatan diri sendiri, dan $8(80 \%)$ orang yang merokok.

Diantara faktor-faktor yang mempengaruhi merokok pada siswa laki-laki antara lain adalah tingkat pengetahuan tentang merokok, sikap tentang merokok, faktor-faktor yang mempengaruhi mereka merokok antara lain salah satu di keluarganya ada perokok, stress menghadapi tekanan di sekolah, ada masalah dengan teman, mengikuti teman yang juga perokok, dan ada masalah keluarga, Penelitian ini dilakukan SMA Negeri 4 Banda Aceh Tahun 2016. Dari hasil wawancara sama guru mengatakan bahwa yang ketahaun merokok di sekolah akan diberikan sangsi-sangsi kepada siswa tersebut dan memanggil orang tuanya.

Berdasarkan latar belakang diatas peneliti tertarik untuk meneliti Berdasarkan latar belakang diatas peneliti tertarik untuk meneliti hubungan pengetahuan, media massa dan lingkungan dengan remaja putra tentang bahaya rokok pada siswa SMA Negeri 4 Banda Aceh Tahun 2016

\section{METODE PENELITIAN}

Penelitian ini menggunakan metode penelitian analitik dengan pendekatan crossectionalyaitu cara pendekatan, observasi atau pengumpulan data sekaligus pada suatu saat, dimana pengumpulan data variabelDependen dan Independen dilakukan penelitian disaat yang bersamaan. Penelitian ini telah dilakukan di SMA Negeri 4 Banda Aceh. Penelitian dilakukan dari bulan Februari s/d Juli 2016, pengambilan data penelitian pada tanggal 18 Juli s.d 25 Juli 2016. Populasi dalam penelitian ini adalah semua siswa laki-laki tingkat 1-III yang ada di SMAN 4 Banda Aceh tahun 2015, yang berjumlah 190 orang. 
Jumlah sampel dalam penelitian 65 orang.

\section{HASIL DAN PEMBAHASAN}

Tabel 1. Ditribusi Frekuensi Sikap Remaja Sikap Remaja Putra Tentang Bahaya Merokok Pada Siswa SMA Negeri 4 Banda Aceh Tahun 2016

\begin{tabular}{clccc}
\hline No & \multicolumn{2}{c}{$\begin{array}{c}\text { Sikap Remaja Tentang } \\
\text { Bahaya Merokok }\end{array}$} & $\begin{array}{c}\text { Frekuensi } \\
\text { (f) }\end{array}$ & Persentase (\%) \\
\hline 1 & Positif & 39 & 60 \\
2 & Negatif & & 26 & 40 \\
\hline \multicolumn{2}{r}{ Total } & 65 & 100 \\
\hline
\end{tabular}

Berdasarkan tabel 1 dapat diketahui bahwa lebih banyak yang sikap remaja positif tentang bahaya merokok yaitu sebanyak 39\% dibandingkan yang sikap remaja negative tentang bahaya merokok.

Tabel 2. Ditribusi Frekuensi Lingkungan Remaja Putra Tentang Bahaya Merokok Pada Siswa SMA Negeri 4 Banda Aceh Tahun 2016

\begin{tabular}{clcc}
\hline No & Lingkungan & $\begin{array}{c}\text { Frekuensi } \\
\text { (f) }\end{array}$ & Persentase (\%) \\
\hline 1 & Mendukung & 33 & 50,8 \\
2 & Tidak Mendukung & 32 & 49,2 \\
\hline & Total & $\mathbf{6 5}$ & $\mathbf{1 0 0}$ \\
\hline
\end{tabular}

Berdasarkan tabel 2 dapat diketahui bahwa lebih banyak yang lingkungan mendukung yaitu sebanyak 50,8\% dibandingkan yang tidak lingkungan mendukung.

Tabel 3. Ditribusi Frekuensi Media Massa Tentang Bahaya Merokok Pada Siswa SMA Negeri 4 Banda Aceh Tahun 2016

\begin{tabular}{clcc}
\hline No & Media Massa & $\begin{array}{c}\text { Frekuensi } \\
\text { (f) }\end{array}$ & Persentase (\%) \\
\hline 1 & Pengaruh & 38 & 58,5 \\
2 & Tidak Pengaruh & 27 & 41,5 \\
\hline Total & $\mathbf{6 5}$ & $\mathbf{1 0 0}$ \\
\hline
\end{tabular}

Berdasarkan tabel 3 dapat diketahui bahwa lebih banyak yang media massa berpengaruhyaitu sebanyak $58,5 \%$ dibandingkan yang media masa tidk berpengaruh 
Tabel 4. Ditribusi Frekuensi Media Massa Tentang Bahaya Merokok Pada Siswa SMA

Negeri 4 Banda Aceh Tahun 2016

\begin{tabular}{clcc}
\hline No & Pengetahuan & $\begin{array}{c}\text { Frekuensi } \\
(\mathbf{f})\end{array}$ & Persentase (\%) \\
\hline 1 & Baik & 35 & 53,8 \\
2 & Kurang Baik & 30 & 46,2 \\
\hline \multicolumn{2}{r}{ Total } & $\mathbf{6 5}$ & $\mathbf{1 0 0}$ \\
\hline
\end{tabular}

Berdasarkan tabel 4 dapat diketahui bahwa lebih banyak yang pengetahuan baik yaitu sebanyak 53,8\% dibandingkan yang pengetahuan kurang baik.

Tabel 5. Hubungan Lingkungan Dengan Sikap Remaja Putra Tentang Bahaya Rokok Pada Siswa SMA Negeri 4 Banda Aceh Tahun 2016

\begin{tabular}{|c|c|c|c|c|c|c|c|c|}
\hline \multirow{3}{*}{ No } & \multirow{3}{*}{ Lingkungan } & \multicolumn{4}{|c|}{$\begin{array}{c}\text { Sikap Remaja Putra } \\
\text { Tentang Bahaya Rokok }\end{array}$} & \multirow{2}{*}{\multicolumn{2}{|c|}{ Total }} & \multirow{3}{*}{$\begin{array}{c}P- \\
\text { value }\end{array}$} \\
\hline & & \multicolumn{2}{|c|}{ Positif } & \multicolumn{2}{|c|}{ Negatif } & & & \\
\hline & & $\mathbf{f}$ & $\%$ & $\mathbf{f}$ & $\%$ & $\mathbf{n}$ & $\%$ & \\
\hline 1 & Mendukung & 25 & 75,8 & 8 & 24,2 & 33 & 100 & \\
\hline 2 & $\begin{array}{l}\text { Tidak } \\
\text { Mendukung }\end{array}$ & 14 & 43,8 & 18 & 56,2 & 32 & 100 & 0,017 \\
\hline
\end{tabular}

Berdasarkan Tabel 5 dapat dilihat bahwa sikap positif tentang bahaya rokok lebih banyak pada responden yang lingkungan mendukung yaitu 75,8\%, dibandingkan dengan lingkungan yang tidak mendukung yaitu hanya $43,8 \%$.

Hasil uji statistic diperoleh nilai $p=0,017$, artinya ada hubungan yang signifikan antara lingkungan dengan sikap remaja putra tentang bahaya rokok pada Siswa SMA Negeri 4 Banda Aceh Tahun 2016.

Tabel 6. Hubungan Media Massa Dengan Sikap Remaja Putra Tentang Bahaya Rokok Pada Siswa SMA Negeri 4 Banda Aceh Tahun 2016

\begin{tabular}{|c|c|c|c|c|c|c|c|c|}
\hline \multirow{3}{*}{ No } & \multirow{3}{*}{ Media Massa } & \multicolumn{4}{|c|}{$\begin{array}{c}\text { Sikap Remaja Putra Tentang } \\
\text { Bahaya Rokok }\end{array}$} & \multirow{2}{*}{\multicolumn{2}{|c|}{ Total }} & \multirow{3}{*}{$\begin{array}{c}P- \\
\text { value }\end{array}$} \\
\hline & & \multicolumn{2}{|c|}{ Positif } & \multicolumn{2}{|c|}{ Negatif } & & & \\
\hline & & f & $\%$ & $\mathbf{f}$ & $\%$ & $\mathbf{n}$ & $\%$ & \\
\hline 1 & Pengaruh & 28 & 73,7 & 10 & 26,3 & 38 & 100 & \\
\hline 2 & Tidak Pengaruh & 11 & 40,7 & 16 & 59,3 & 27 & 100 & 0,016 \\
\hline
\end{tabular}


Berdasarkan Tabel 6 dapat dilihat bahwa sikap positif tentang bahaya rokok lebih banyak dijumpai pada responden yang pengaruh dengan media massa yaitu $73,7 \%$, dibandingkan dengan responden yang tidak pengaruh yaitu hanya $40,7 \%$.

Hasil uji statistic diperoleh nilai $\mathrm{p}=0,016$, artinya ada hubungan yang signifikan antara media massa dengan sikap remaja putra tentang bahaya rokok pada Siswa SMA Negeri 4 Banda Aceh Tahun 2016.

Tabel 7. Hubungan Pengetahuan Dengan Sikap Remaja Putra Tentang Bahaya Rokok Pada Siswa Negeri 4 Banda Aceh Tahun 2016

\begin{tabular}{|c|c|c|c|c|c|c|c|c|}
\hline \multirow{3}{*}{ No } & \multirow[t]{3}{*}{ Pengetahuan } & \multicolumn{4}{|c|}{$\begin{array}{c}\text { Sikap Remaja Putra Tentang } \\
\text { Bahaya Rokok }\end{array}$} & \multirow{2}{*}{\multicolumn{2}{|c|}{ Total }} & \multirow[t]{3}{*}{ P-value } \\
\hline & & \multicolumn{2}{|c|}{ Positif } & \multicolumn{2}{|c|}{ Negatif } & & & \\
\hline & & $\mathbf{f}$ & $\%$ & f & $\%$ & n & $\%$ & \\
\hline 1 & Baik & 26 & 74,3 & 9 & 25,7 & 35 & 100 & \\
\hline 2 & Kurang Baik & 13 & 43,3 & 17 & 56,7 & 30 & 100 & 0,022 \\
\hline
\end{tabular}

Berdasarkan Tabel 7 dapat dilihat bahwa sikap positif tentang bahaya rokok lebih banyak dijumpai pada responden yang berpengetahuan baik yaitu 74,3\%, dibandingkan dengan responden yang berpengetahuan kurang baik hanya 43,3\%.

Hasil uji statistic diperoleh nilai $\mathrm{p}=0,022$, artinya ada hubungan yang signifikan antara pengetahuan dengan sikap remaja putra tentang bahaya rokok pada Siswa SMA Negeri 4 Banda Aceh Tahun 2016.

\section{Pembahasan}

1. Hubungan Lingkungan Dengan Sikap Remaja Putra Tentang Bahaya Rokok Pada Siswa Berdasarkan Tabel 5 dapat dilihat bahwa sikap positif tentang bahaya rokok lebih banyak pada responden yang lingkungan mendukung yaitu 75,8\%, dibandingkan dengan lingkungan yang tidak mendukung yaitu hanya $43,8 \%$.

Hasil uji statistic diperoleh nilai $\mathrm{p}=0,017$, artinya ada hubungan yang signifikan antara lingkungan dengan sikap remaja putra tentang bahaya rokok pada Siswa SMA Negeri 4 Banda Aceh Tahun 2016.

Hasil penelitian oleh Emi (2010) yang berjudul Faktor - Faktor Yang Mempengaruhi Sikap Remaja Putra Tentang Bahaya Merokok Di Smp Negeri 2 Baktiya Kecamatan Baktiya Kabupaten Aceh Utara Tahun 2010 dapatkan sebagian besar 
responden mempunyai persentase tertinggi pengetahuan remaja putra berdasarkan lingkungan tempat tinggal perkotaan yaitu 55 responden $(57,9 \%)$ dan berdasarkan lingkungan tempat tinggi pedesaan yaitu 40 responden $(42,1)$ Hasil uji statistic diperoleh nilai $\mathrm{p}=0,010$, artinya ada hubungan antara lingkungan dengan sikap remaja putra tentang bahaya rokok.

Hasil Penelitian Lukman (2012) Yang berjudul Faktor-FaktorYang Mempengaruhi Perilaku bahaya Merokok Pada Remaja di Sma Negeri 2 Mamuju Kab. Mamuju Tahun 2012" dari 67 responden yang mendapat pengaruh lingkungan terdapat 62 responden $(92,5 \%)$ yang merokok dan 5 responden $(7,5 \%)$ yang tidak merokok. Dari 15 responden yang tidak mendapat pengaruh psikososial terdapat 8 responden $(53,3 \%)$ yang merokok dan 7 responden $(46,7 \%)$ yang tidak merokok. Ada pengaruh antara lingkungan terhadap bahaya merokok pada remaja di SMA Negeri 2 Mamuju Kab.Mamuju Tahun 2014, ditandai dengan nilai $p$-value $(0,000)<$ dari $\alpha$-value $(0,05)$.

Lingkungan adalah tempat berkembanganya perilaku terhadap kebiasaan yang ada di lingkungan. Lingkungan yang kurang baik akan berpengaruh pada perkembangan jiwa seseorang. Hal-hal yang tidak baik yang diterimanya dalam interaksi menjadi hal yang biasa baginya. Lingkungan yang tidak baik dapat mempengaruhi seseorang untuk melanggar norma-norma yang ada di dalam masyarakat, (Yunita,2009).

Lingkungan keluarga dan teman berhubungan dengan perilaku merokok.Teman merupakan faktor yang lebih dominan dalam mempengaruhi perilaku merokok (Maharani, 2011). Guru sebagai bagian dari lingkungan sekolah diharapkan dapat terlibat secara aktif pada upaya pencegahan perilaku merokok pada remaja. Akan tetapi keterlibatan guru dalam belum maksimal. Keterlibatan guru masih tergantung pada karakteristik kepribadian guru dan jenis sistem yang diterapkan sekolah (Susanto, 2008). Iklan juga termasuk faktor lingkungan yang kuat mempengaruhi tindakan merokok (Hasanah, 2011). Penelitian membuktikan peringatan tertulis beserta gambar lebih efektif daripada yang berisis hanya tulisan saja (Departemen Kesehatan, 2012).

Menurut asumsi penelitian terdapat hubungan antara lingkungan dengan sikap remaja putra tentang bahaya rokok pada Siswa, lingkungan sangat mempengaruhi remaja merokok, Lingkungan merupakan tempat berkembanganya perilaku terhadap kebiasaan yang ada di lingkungan. Lingkungan yang kurang baik akan berpengaruh pada perkembangan jiwa seseorang. Hal-hal yang tidak baik yang diterimanya dalam interaksi 
menjadi hal yang biasa baginya dan semakin baik lingkungan terhadap remaja putra, maka semakin lingkungan yang mendukung dengan sikap remaja tentang bahaya merokok.

2. Hubungan Media Massa Dengan Sikap Remaja Putra Tentang Bahaya Rokok Pada Siswa Berdasarkan Tabel 6 dapat dilihat bahwa sikap positif tentang bahaya rokok lebih banyak dijumpai pada responden yang pengaruh dengan media massa yaitu $73,7 \%$, dibandingkan dengan responden yang tidak pengaruh yaitu hanya 40,7\%.

Hasil uji statistic diperoleh nilai $p=0,016$, artinya ada hubungan yang signifikan antara media massa dengan sikap remaja putra tentang bahaya rokok pada Siswa SMA Negeri 4 Banda Aceh Tahun 2016.

Hasil penelitian Rosmanijar (2012), yang berjudul Faktor - Faktor Yang Berhubungan Dengan Status Merokok Pada Siswa Sekolah Menengah Atas Negeri 5 Banda Aceh. responden yang mempunyai pengaruh positif, terdapat 12 (37,5\%) yang merokok, $20(62,5 \%)$ responden yang tidak merokok, dalam artian pada kategori positif terdapat banyak responden yang tidak merokok dibandingkan dengan yang merokok. Dan 39 responden yang mempunyai pengaruh negatif, terdapat $29(74,4 \%)$ responden yang merokok, $10(25,6 \%)$ responden yang tidak merokok. Berdasarkan perhitungan uji Chi Square, diperoleh nilai $p$-value $=0,01$ Nilai tersebut lebih kecil dari $(p<0,05)$, dengan demikian ada hubungan antara Iklan dengan Status Merokok atau Hipotesa alternatif (Ha) diterima.

Hasil penelian Emi (2012) yang berudul tentangfaktor-factor yang mempengaruhi pengetahuan remaja putra tentang bahaya merokok di SMP negeri 2 Baktiya Kabupaten Aceh Utara Tahun 2010, persentase tertinggi pengetahuan remaja putra berdasarkan Informasi yang didapatkan dari media elektronik yaitu 34 responden $(35,8 \%)$ dan persentase terendah didapatkan dari Petugas Kesehatan yaitu 30 responden (31,5\%). diperoleh nilai $p$-value $=0,001(p<0,05)$, dengan demikian ada hubungan antara Iklan dengan tentang bahaya merokok.

Media masa elektronik maupun media cetak sangat besar pengaruhnya terhadap pembentukan opini dan kepercayaan seseorang. Dengan pemberian informasi melalui media masa mengenai sesuatu hal yang akan memberikan landasan kognitif baru bagi terbentuknya sikap. Banyak faktor yang mendorong dan mempengaruhi remaja untuk merokok,salah satunya adalah iklan. Iklan merupakan suatu media untuk 
menyampaikaninformasi kepada masyarakat terhadap suatu produk dan iklan memiliki fungsiuntuk menyampaikan informasi, membujuk, atau untuk mengingatkanmasyarakat terhadap produk rokok.Dengan melihat iklan yang ada di televisi dan media massa, remajamulai mengenal dan mencoba untuk merokok karena gencarnya iklan rokokyang beredar di masyarakat, ditambah dengan adanya image yang dibentuk olehiklan rokok sehingga terlihat seakan orang yang merokok adalah orang yangsukses dan tangguh yang dapat melalui rintangan apapun (Alamsyah, 2007).

Reklame tembakau diperkirakan mempunyai pengaruh yang lebih kuat dari pada pengaruh orang tua atau teman sebaya, mungkin karena mempengaruhi persepsi remaja terhadap penampilan dan manfaat merokok. Memulai menggunakan tembakau lebih erat hubungannya dengan faktor-faktor lingkungan, sedangkan peningkatan dari merokok pertama kekecanduan rokok tampaknya dipengaruhi oleh faktor personal dan farmakologik (Soetjiningsih, 2004).

Menurut asumsi penelitian terdapat hubungan antara media massa dengan sikap remaja putra tentang bahaya rokok pada siswa melihat dari iklan di media massa dan elektronik yang menampilkan pesan yang tersirat bahwa perokok adalah lambang kejantanan atau glamour, membuat remaja sering kali terpicu untuk mengikuti perilaku seperti yang ada dalam iklan tersebut. Korban dari iklan rokok yang sangat gencar baik dari media cetak, maupun elektronik dan yang paling mendorong lagi, remaja tersebut merokok adalah karena figure idolanya merokok.Iklan punya peran penting dalam menentukan dan mendorong kebiasaan merokok pada masyarakat.

3. Hubungan Pengetahuan Dengan Sikap Remaja Putra Tentang Bahaya Rokok Pada Siswa

Berdasarkan Tabel 7 dapat dilihat bahwa sikap positif tentang bahaya rokok lebih banyak dijumpai pada responden yang berpengetahuan baik yaitu 74,3\%, dibandingkan dengan responden yang berpengetahuan kurang baik hanya 43,3\%.

Hasil uji statistic diperoleh nilai $\mathrm{p}=0,022$, artinya ada hubungan yang signifikan antara pengetahuan dengan sikap remaja putra tentang bahaya rokok pada Siswa SMA Negeri 4 Banda Aceh Tahun 2016.

Hasil penelitian Nuriati, (2010), yang bejudul Rendahnya Pengetahuan Remaja Tentang BahayaMerokok Bagi Kesehatan Reproduksi Di Desa Lhok Rambideng Kecamatan"Seunuddon" pengetahuan remaja didapatkan bahwa dari 2 orang pengetahuan 
baik ternyata 1 orang (50\%) bahaya, sedangkan dari 21 orang pengetahuan cukup ternyata 15 orang (71\%) bahaya, dan dari 19 orang pengetahuan kurang ternyata 8 orang (42\%) bahaya. Hasil uji statistic diperoleh nilai $\mathrm{p}=0,009$, artinya ada hubungan yang signifikan antara pengetahuan dengan sikap remaja putra tentang bahaya rokok.

Hasil penelian Emi (2012) yang berjudul tentangfaktor-faktoryang mempengaruhi pengetahuan remaja putra tentang bahaya merokok di SMP negeri 2 Baktiya KabupatenAceh UtaraTahun2010,responden mempunyai pengetahuan baik yaitu 44 responden sebanyak (46,3\%) tentang bahaya merokok, adapun yang berpengatahuan cukup sebanyak 4 responden (10,5\%)) tentang bahaya merokok dan yang berpengetahuan kurang 10 responden $(31,5 \%)$ dan diperoleh nilai $p$-value $=0,001(p<0,05)$, dengan demikian ada hubungan antarap pengetahyan dengan tentang bahaya merokok.

Pengetahuan adalah hasil dari penginderaan manusia terhadap objek tertentu melalui indera yang dimilikinya. Pengetahuan yang dihasilkan dipengaruhi oleh intensitas perhatian terhadap objek. Pengetahuan merupakan domain penting untuk terbentuknya suatu tindakan seseorang (Notoatmodjo, 2010). Menurut Mubarak et al (2007) pengetahuan merupakan hasil dari mengingat kembali kejadian yang pernah dialami baik secara sengaja maupun tidak sengaja setelah dilakukan pengamatan pada suatu obyek.

Tingkat pengetahuan yang paling rendah, disini subjek mengetahui apa itu rokok dan rokok telah dikenal atau dipelajari sebelumnya. Subjek akan dapat menyebutkan, menguraingi ataupun mendefinisikan secara benar apa yang dimaksud dengan rokok, misalnya : seseorang mengetahui apa itu rokok, jenis-jenis rokok yang ada di pasaran, ataupun menjelaskan rokok itu dari sudut pandangnya. Memahami merupakan tingkat yang lebih tinggi dari tahu.Disini subjek memiliki kemampuan untuk menjelaskan dan mengintrepretasikan rokok secara benar. Sedangkan pada tingkat aplikasi, subjek mampi menggunakan pengetahuannya mengenai rokok dalah kondisi atau situasi yang sesungguhnya, misalnya: seseorang yang telah mengerti akan bahaya asap rokok, dan dia akan keluar dari ruangan yang penuh dengan asap rokok tersebut guna menjaga kesehatan, (Notoadmodjo, 2010).

Menurut asumsi penelitian bahwa terdapat hubungan antara pengetahuan dengan sikap remaja putra tentang bahaya rokok pada Siswa, pengetahuan sangat mempengeruhi bagi remaja putra, Pengetahuan merupakan hasil"tahu" dan ini terjadi setelah orang 
melakukan penginderaan terhadap suatu objek tertentu. Penginderaan terjadi melalui panca indera manusia, yaitu indera penglihatan, pendengaran, penciuman, rasa dan raba. Maka semakin baik pengetahuan remaja putra maka semakin baik pula pola berpikir terhadap bahaya-bahaya merokok, karena merokok dapat membahayakan bagi kesehatannya.

\section{KESIMPULAN}

Berdasarkan hasil penelitian yang telah dilakukan maka penelitian dapat mengumpulkan hasil dari penenelitian sebagai berikut :

1. Ada hubungan antara lingkungan dengan sikap remaja putra tentang bahaya rokok pada Siswa SMA Negeri 4 Banda Aceh Tahun 2016, p-value = 0,017

2. Ada hubungan antara media massa dengan sikap remaja putra tentang bahaya rokok pada Siswa SMA Negeri 4 Banda Aceh Tahun 2016, p-value = 0,016

3. Ada hubungan antara pengetahuan dengan sikap remaja putra tentang bahaya rokok pada Siswa SMA Negeri 4 Banda Aceh Tahun 2016, p-value = 0,022.

\section{SARAN}

Diharapkan untuk dinas Pendidikan agar secara berkala memberikan penyuluhan berupa informasi mengenai efek merokok terhadap kesehatan terutama mengenai penyakit yang ditimbulkan dari merokok kepada para siswa dan memasang poster tentang bahaya merokok agar para siswa lebih menyadari dampak yang dapat ditimbulkan dari merokok. Diharapkan kepada kepala sekolah dan para guru untuk dapat meningkatkan pengawasan terhadap para siswa agar tidak ada siswa yang merokok baik dilingkungan sekolah maupun diluar sekolah.

\section{DAFTAR PUSTAKA}

Agustiani, Hendriati. (2006).PsikologiPerkembangan.Bandung:RefikaAditama

BPOM RI, (2010),Hubungan Antara Pengetahuan dan Sikap Tentang Bahaya Merokok Dengan Tindakan Merokok Remaja di Pasar Baser hatiK ota Manado.Manado:Universitas Samratulangi, Jurnal

Eva (2013) Faktor-faktor yang Berhubungan dengan Status Merokok pada Siswa SMA Negeri 5 Banda Aceh Tahun 2013, Jurnal

Badan PusatStatistik. (2011).Klasifikasi Perkotaan dan Pedesaan diIndonesia 
KementerianKesehatanR.I. (2012).RisetKesehatanDasar2010. Jakarta:BadanPenelitian dan Pengembangan Kesehatan.

Kementerian KesehatanR.I. (2010). Pedoman PengembanganKawasan Tanpa Rokok.Jakarta:PusatPromosiKesehatan.

Notoatmodjo.(2010).Ilmu Perilaku Kesehatan.Jakarta:RinekaCipta.

Notoatmodjo.(2010).MetodePenelitian Kesehatan.Jakarta:RinekaCipta.

Notoadmodjo, Soekidjo (2007). “Metodologi Penelitian Kesehatan”. PT. Rineka Cipta : Jakarta.

Tarwotoetal. (2011).KesehatanRemaja:Problem danSolusinya.Jakarta:Salemba Medika

Tarwotoetal. (2009).KesehatanRemaja:Problem danSolusinya.Jakarta:Salemba Medika 